\title{
PENGARUH PERENCANAAN PAJAK DAN BEBAN PAJAK TANGGUHAN TERHADAP MANAJEMEN LABA
}

\section{(Studi empiris pada perusahaan property dan real estate yang terdaftar di BEI tahun 2014-2018)}

\author{
Sules Jayanti, M. Sodik, Hartini P. P \\ Universitas Widyagama Malang
}

\begin{abstract}
ABSTRAK
Penelitian ini bertujuan untuk menganalisis pengaruh perencanaan pajak dan beban pajak tangguhan terhadap manajemen laba. Obyek dalam penelitian ini adalah 120 laporan keuangan tahunan perusahaan property dan real estate yang terdaftar di Bursa Efek Indonesia (BEI), periode pengamatan 5 tahun, mulai tahun 2014 sampai dengan tahun 2018. Data yang digunakan pada penelitian ini adalah data sekunder diperoleh melalui situs resmi BEI yaitu, www.idx.co.id. Metode pengambilan sampel menggunakan purposive sampling, metode analisis data menggunakan statistik deskriptif dan regresi logistik biner. Hasil penelitian menunjukkan bahwa, perencanaan pajak memiliki pengaruh negatif dan tidak signifikan terhadap manajemen laba. Berbeda dengan beban pajak tangguhan berpengaruh positif dan tidak signifikan terhadap manajemen laba. Artinya, peningkatan perencanaan pajak tidak mempengaruhi peningkatan peluang perusahaan dalam melakukan manajemen laba dalam bidang perpajakan dan beban pajak tangguhan mempengaruhi peningkatan peluang serta probabilitas perusahaan dalam melakukan manajemen laba. Selain itu, hasil pada statistik deskriptif menunjukkan kemungkinan terjadinya manajemen laba dengan tujuan menghindari penurunan laba.
\end{abstract}

Kata Kunci: Perencanaan pajak, beban pajak tangguhan, manajemen laba 


\section{PENDAHULUAN}

Pencapaian laba perusahaan secara umum tercermin pada kinerja suatu perusahaan. Pihak ketiga memerlukan informasi laba untuk mengambil keputusan dan keberlangsungan operasional perusahaan termasuk besaran pajak. Kualitas informasi laba yang dilaporkan, secara langsung menyedot perhatian pihak ketiga salah satunya investor dan Direktorat Jendral Pajak (DJP).

Tim pengelola perusahaan secara langsung yaitu manajemen menginginkan mendapat laba yang tinggi dan mempengaruhi bonus yang didapatkan manajemen nantinya. Sehingga manajemen bertanggungjawab atas pelaporan laba yang dapat memberikan informasi serta membantu pemilik (stakeholders) dalam melakukan estimasi kekuatan laba (earnings power) guna mempertimbangkan resiko investasi maupun kredit perusahaan.

Perusahaan properti dan real estate yang berada di Indonesia juga tidak lepas dari arus persaingan pasar global. Kuantitas produk, kualitas produk, pengelolaan keuangan dan pengendalian perusahaan dituntut mempunyai keunggulan bersaing demi menjamin keberlangsungan perusahaan. Besarnya laba yang diharapkan dengan laba yang dicapai, mendorong manajer perusahaan untuk melakukan kecurangan dalam menyajikan dan melaporkan laba familiar dengan praktek manajemen laba (earnings management).

Sulistyanto mengungkapkan bahwa, usaha manajer mempengaruhi informasi pada laporan keuangan, dengan maksud membohongi pemilik (stakeholder) yang ingin mengetahui kondisi dan kinerja perusahaan disebut manajemen laba. Intervensi dan membohongi digunakan pedoman sebagian pihak dalam menilai manajemen laba sebagai hal yang negatif atau kecurangan (Sulistyanto, 2008 : 6). Sedangkan menurut Belkaoui mendefinisikan kemampuan manipulasi pilihan yang tersedia dan mengambil pilihan yang tepat, guna mencapai laba yang diinginkan dikenal dengan manajemen laba (earnings management) (Belkaoui, 2006 : 74). Scoot berpendapat ada tiga cara dalam melakukan praktek manajemen laba yaitu, income smoothing, income maximization dan taking a bath (Scoot, 2000 : 383). Negara mengemukakan pada penelitiannya manajemen laba dapat dijelaskan melalui teori keagenan, dimana masalah setiap pihak timbul berusaha mendapatkan kemakmuran yang diharapkannya yaitu, pihak yang berkepentingan dengan manajemen pihak yang menjalankan kepentingan (Negara, et al., 2017).

Manajemen menginginkan pembayaran pajak yang seminim mungkin, maka melakukan upaya perencanaan pajak yaitu, menekan beban pajak secara eufimisme (Suandy, 2014 : 1). Perencanaan pajak lebih condong terhadap strategi menekan beban pajak sekecil mungkin tetapi tidak melanggar hukum pajak yang berlaku.

Penerimaan negara terbesar salah satunya dari pajak penghasilan untuk melakukan pembangunan negara (Aditama, et al,. 2014). Laporan keuangan di Indonesia harus mengikuti PSAK, termasuk akuntansi pajak penghasilan untuk memperoleh laporan keuangan yang informatif serta kredibel. Disisi lain perusahaan dituntut untuk 
menyajikan pelaporan laba rugi dengan undang-undang perpajakan. Maka timbulah perbedaan (difference) antara laba fiskal (penghasilan kena pajak) dengan laba komersial (laba sebelum pajak).

Perbedaan tersebut menimbulkan masalah pada penentuan besarnya laba, sehingga saldo akhir tidak balance. Rekonsiliasi fiskal diperlukan untuk membalancekan saldo akuntasi dengan saldo fiskal, otomatis memunculkan beban pajak tangguhan (Sumomba, et al., 2012). Sehingga menjadi pemicu manajer dalam mensiasati laba menjadi besar.

Hal ini juga sejalan dengan penelitian Phillips, Pincus dan Rego mengemukakan secara signifikan beban pajak tangguhan digunakan mendeteksi manajemen laba dalam menghindari penurunan laba serta menghindari kerugian (Phillips, et al., 2003). Di Indonesia, Christina Ranty Sumomba dan Y.B Sigit Hutomo yang meneliti pada perusahaan manufaktur di BEI, mendapatkan hasil bahwa beban pajak tangguhan dan perencanaan pajak dapat digunakan dalam mendeteksi praktek manajemen laba (Sumomba, et al., 2012). Selain itu, Ferry Aditama dan Anna Purwaningsih melakukan penelitian pada perusahaan non-manufaktur yang terdaftar di BEI, mengungkapkan perencanaan pajak tidak berpengaruh secara signifikan terhadap manajemen laba. Tetapi perusahaan terdeteksi melakukan manajemen laba untuk menghindari penurunan laba (Aditama, et al., 2014). Adapun penelitian Dewa Ketut Wira Santana dan Made Gede Wirakusuma pada perusahaan manufaktur yang terdaftar di BEI, perencanaan pajak mempunyai pengaruh positif. Tarif PPh badan yang berubah, mempengaruhi perilaku perusahaan melakukan praktek manajemen laba (Santana, et al., 2016). Selanjutnya, berdasarkan penelitian A.A Gede Raka Plasa Negara dan I.D.G Dharma Suputra pada perusahaan manufaktur di BEI, mengindikasikan perencanaan pajak dan beban pajak tangguhan berpengaruh secara signifikan terhadap kemungkinan perusahaan melakukan manajemen laba (Negara, et al., 2017).

Manajemen laba merupakan area yang menarik pada akuntansi keuangan. Laporan keuangan tidak lagi menjadi kredibel dan mempunyai nilai fundamental pada perusahaan, karena usaha yang dilakukan perusahaan dalam mempercantik informasi keuangan dengan praktek manajemen laba. Penulis mencoba menyatukan variabel perencanaan pajak dan beban pajak tangguhan terhadap manajemen laba, dengan judul penelitian "Pengaruh Perencanaan Pajak dan Beban Pajak Tangguhan Terhadap Manajemen Laba (Studi Empiris Pada Perusahaan Property dan Real Estate yang Terdaftar di BEI Tahun 2014-2018)".

Berdasar latar belakang masalah tersebut, pokok permasalahan pada penelitian ini yaitu, 1. Apakah perencanaan pajak dapat mempengaruhi manajemen laba?; 2. Apakah beban pajak tangguhan dapat mempengaruhi manajemen laba?. Sepakat dengan perumusan masalah di atas, penelitian ini bertujuan untuk menguji seberapa besar perencanaan pajak dan beban pajak tangguhan digunakan dalam mempengaruhi praktek manajemen laba. 


\section{TINJAUAN PUSTAKA}

\subsection{Perencanaan Pajak}

Usaha menekan beban pajak seefektif mungkin, untuk mencapai laba yang semaksimal mungkin dikenal dengan perencanaan pajak. Perencanaan pajak ialah step pertama pada manajemen pajak. Wajib pajak dapat menerapkan beberapa metode, yakni: (Lumbantoruan, 1996 : 489):

a Pengalihan beban pajak dari sujek pajak ke pihak ketiga dikenal dengan (tax shifting) pergeseran pajak.

b. Jumlah pajak yang akan dibayar pihak pembeli sama dengan pengurangan harga objek pajak dikenal dengan kapitalisasi.

c. Penghindaran pajak dengan menanggung beban pajak yang dikenakan dikenal dengan transformasi.

d. Penghindaran pajak secara ilegal di luar undang-undang perpajakan dikenal dengan (tax evasion) penggelapan pajak.

e. Upaya wajib pajak mengefisiensikan beban pajak dalam bingkai peraturan perpajakan yang berlaku dikenal dengan (tax avoidance) penghindaran pajak.

Zain mengemukakan bahwa, tindakan terstruktur yang menekan pada transaksi berpotensi kepada konsekuensi pajak, dengan tujuan efisiensi jumlah pajak secara legal tidak menyalahi aturan kepada pemerintah familiar dikenal dengan penghindaran pajak (Zain, 2003 : 67). Tidak jauh beda dengan Zain, Suandy juga menjabarkan suatu proses pengorganisasi hutang pajak dan beban pajak yang lain dalam tingkat yang sekecil mungkin oleh wajib pajak disebut perencanaan pajak (Suandy, 2014 : 6).

Secara keseluruhan apabila ditinjau dari tujuan, penghindaran pajak dengan perencanaan pajak secara hakikatnya sama, karena sama-sama bertujuan untuk meminimumkan beban pajaknya, serta memaksimalkan laba setelah pajak (earnings after tax). Apabila anggaran pajak efisien, maka anggaran tersebut sisanya dapat diputuskan untuk investasi maupun dibagi kepada pemegang saham. Apabila hal yang terjadi adalah transaksi terkena pajak, maka dapatkah pengecualian penundaan dalam pembayaran pajak.

\subsection{Beban Pajak Tangguhan}

Beban pajak tangguhan terjadi akibat perbedaan temporer antara laba komersial dengan laba fiskal pada laporan keuangan, sehingga menyebabkan pengakuan aset pajak tangguhan dan liabilitas pajak tangguhan. Menurut Harnanto, beban muncul karena beda temporer laba akuntansi dan laba fiskal disebut beban pajak tangguhan (Harnanto, 2011 : 115).

Jika terdapat pembayaran lebih besar di periode akan datang, harus diakui kewajiban berdasar PSAK (Suandy, 2014 : 91). Misalnya beban depresiasi aset tetap secara akuntansi karena beda metode penyusutan, sehingga selisih berakibat pada pengakuan beban pajak akuntansi lebih tinggi di masa depan akan menyebabkan kewajiban pajak tangguhan. Kewajiban pajak tangguhan timbul jika koreksi fiskal 
negatif, dimana pendapatan akuntansi lebih dominan dari pendapatan fiskal (Agoes, et al., 2013 : 110).

Kewajiban pajak tangguhan diakui saat beda temporer kena fiskal, tidak seluruh beda temporer bisa dikurangkan demi pajak, berikut pengecualiannya (Purba, 2009 : $35)$ :

a) Kewajiban pajak tangguhan yang berasal dari beda temporer investasi pada perusahaan asosiasi, anak perusahaan dan joint venture tidak diakui apabila induk perusahaan dan partner dapat mengendalikan waktu reversal beda temporer tersebut.

b) Kewajiban pajak tangguhan tidak diakui dari beda temporer yang muncul dari pengakuan awal goodwill yang berasal dari penggabungan usaha.

c) Kewajiban pajak tangguhan tidak diakui dari beda temporer yang muncul dari pengakuan aktiva dan kewajiban dalam suatu transaksi yang bukan merupakan transaksi penggabungan usaha. Transaksi penggabungan usaha tersebut tidak mempengaruhi baik laba akuntansi (komersial) maupun laba yang dikenakan pajak (fiskal).

Metode akuntansi PPh dengan pendekatan neraca mengakui kewajiban serta aktiva pajak tangguhan atas konsekuensi fiskal masa depan karena beda temporer serta belum dikompensasikan. Beda temporer yang bisa menambah jumlah pajak masa akan datang diakui hutang pajak tangguhan serta perusahaan wajib mengakui deferred tax expense, artinya setiap kenaikan hutang pajak tangguhan perusahaan mengakui pendapatan awal atau meninda biaya demi laporan akuntansi daripada laporan fiskal. Serta beda temporer mengurangi jumlah pajak masa datang diakui aktiva pajak tangguhan dan perusahaan mengakui manfaat pajak tangguhan, artinya setiap kenaikan pajak tangguhan perusahaan mengakui biaya awal atau menangguhakan pendapatan demi laporan akuntansi daripada laporan fiskal (Wijayanti, 2015) dalam (Wisyam, 2017).

\subsection{Manajemen Laba}

Ukuran kinerja perusahaan selalu dijadikan pedoman dalam mengambil keputusan, ukuran tersebut tercermin dari laba yang dihasilkan karena memiliki nilai dalam peramalan. Hal tersebut yang memicu manajemen menerapkan praktek manajemen laba untuk menunjukkan kesehatan kinerja perusahaan di depan pihak ketiga. Menurut Wisyam, Upaya manajer dalam manipulasi angka akuntansi yang disajikan untuk pihak ketiga dengan maksud kemakmurannya melalui pengubahan atau pengabaian PSAK, sehingga tidak tersajinya informasi laporan keuangan dengan real disebut manajemen laba (Wisyam, 2017).

Manajemen beralasan menerapkan praktek manajemen laba untuk mendongkrak kepercayaan investor kepada perusahaan. Laba berkaitan dengan prestasi yang dicapai perusahaan, sehingga manajemen akan memperoleh bonus senilai peningkatan laba. Hingga sekarang praktek manajemen laba masih kontroversi pada laporan keuangan, padahal tidak semua praktek manajemen laba berkonotasi negatif yakni, manipulasi data. Padahal praktek manajemen laba cenderung berkaitan dengan pemilihan metode akuntansi, dengan maksud batasan GAAP. 


\subsection{Teori Manajemen Laba}

a. Teori keagenan (agency theory)

Dasar manajemen laba berawal dari pendekatan teori agency, menurut pendapat Jensen dan Meckling hubungan kepentingan manajemen sebagai agen dengan investor sebagai principal, menimbulkan konflik dalam pelaporan kualitas laba. Konflik kepentingan yakni, agen mempunyai kewajiban pengelolaan emiten seperti yang dipercayakan principal, sedangkan principal sebagai penyedia dana serta fasilitas untuk operasional emiten (Sulistyanto, 2008 : 96).

Pada teori ini mengasumsikan setiap individu hanya termotivasi atas kesejahteraan serta kepentingannya sendiri. Agen termotivasi atas kesejahteraan dari tingginya kompensasi, principal termotivasi atas kesejahteraan dari pembagian deviden serta naiknya harga saham emiten. Konflik terus menguat saat principal mendapatkan informasi yang minim atas kinerja agen terhadap emiten dan agen, akibatnya terjadi asimetri informasi atas laba sehingga terdorong keinginan agen menyembunyikan informasi pelaporan keuangan dengan praktek manajemen laba (Aditama, et al., 2014).

Konflik tersebut menimbulkan biaya keagenan, biaya tersebut dapat diminimumkan melalui mekanisasi pengawasan dengan menyejajarkan kepentingan tersebut. Principal mengomando agar agen tidak over dalam pemegangan kas, sebab kas merupakan salah satu pemicu agen berbuat kecurangan (Herdawati, 2015).

b. Teori Akuntansi Positif (Positive accounting theory)

Teori ini berusaha membuat ramalan yang baik sesuai kondisi, ramalan tersebut berkaitan dengan tindakan dan respon manajer pada pemilihan metode akuntansi serta standar akuntansi yang baru (Scoot, 2006). Menurut pandangan Watt, teori akuntansi positif bertujuan memaparkan serta meramal akibat atau efek dari keputusan yang di ambil manajer kepada pihak yang berkepentingan (Watt, et al., 1990).

Anis dan Iman berpendapat, teori akuntansi positif adalah bagian dari teori keagenan, sebab teori akuntansi positif mengakui hubungan manajer dengan pihak berkepentingan (Aditama, et al., 2014).

Menurut Watt serta Zimmerman teori akuntansi positif berkaitan dengan perilaku kesempatan manajer dan menghasilkan hipotesis, yakni (Scoot, 2000):

\section{1) Bonus Plan Hypothesis}

Pilihan manajer dalam metode akuntansi dengan tujuan memperoleh bonus yang tinggi berdasar laba, maka akan memilih metode peningkatan pelaporan laba.

\section{2) Debt Covenant Hypothesis}

Pilihan manajer dalam metode akuntansi dengan tujuan menghindari perjanjian hutang atau menunda pembayaran hutang tanpa dikenakan sanksi, maka akan memilih metode peningkatan pelaporan pendapatan atau laba.

\section{3) The Political Cost Hypothesis}


Pilihan manajer dalam metode akuntansi dengan tujuan meminimumkan atau mengefisenkan beban pajak yang ditanggung perusahaan, maka akan memilih metode menurunkan pelaporan laba.

\subsection{Pengukuran Manajemen laba}

Penerapan praktek manajemen laba adalah hal yang rasional, sebab kelenturan akuntansi memungkinkan manajer mencampuri pelaporan keuangan perusahaan, untuk pengungkapan dan evaluasi praktek manajemen laba peneliti memproksikan dengan pendekatan perataan laba atau distribusi laba (Phillips, et al., 2003). Pendekatan perataan laba atau distribusi laba menjelaskan adanya batas pelaporan laba (earnings thresholds), apabila perusahaan di bawah batas pelaporan laba maka manajer berupaya melewati batas tersebut dengan penerapan praktek manajemen laba. Phillips, Pincus dan Rego memaparkan bahwa, manajer menerapkan praktek manajemen laba melalui pendekatan perataan laba atau distribusi laba, sebab manajer tahu bahwa pihak ketiga mempergunakan earnings thresholds dalam penilaian kinerja perusahaan (Phillips, et al., 2003).

Pada penelitian yuliati (2005) memperlihatkan perusahaan menerapkan manajemen laba dengan maksut penghindaran rugi, hal tersebut dibuktikan melalui perusahaan banyak yang melaporkan rendahnya laba (small profit firms) dari pada yang melaporkan rendahnya rugi (small loss firms). Burgstahler dan Dichev (1997) dalam Yulianti (2005) serta Phillips, Pincus dan Rego (2003) mengunggkapkan berubahnya laba di daerah batas pelaporan laba serta patahnya distribusi laba, harusnya mengikuti model distribusi normal. Hal itu disebabkan:

a) Pelaporan laba nol, memperlihatkan upaya perusahaan menerapkan praktek manajemen laba menghindari laporan rugi.

b) Perubahan laba nol, memperlihatkan upaya perusahaan menerapkan praktek manajemen laba menghindari turunnya laba.

\subsection{Kerangka Konseptual Penelitian}

Demi mendapatkan kemakmuran serta tujuan, perusahaan berupaya dalam berbagai cara untuk memaksimalkan keuntungan, meskipun merekayasa laporan keuangan yang tersaji disebut manajemen laba. Manajemen laba sering dipasangkan dengan perencanaan pajak dan beban pajak tangguhan dalam mendeteksi praktek manajemen laba. Motif perusahaan menerapkan perencanaan pajak dengan efektif, akan menerima profit fiskal serta profit tambahan modal investor dari penjualan saham perusahaan.

Maka, pajak adalah pengurang laba yang akan di share ke investor maupun diinvestasikan perusahaan, manajemen berupaya meminimalkan untuk memaksimalkan total net profit perusahaan. Kondisi seperti ini, mengindikasikan manajemen menerapkan praktek manajemen laba pada proses perencanaan pajak.

Sama halnya dengan beban pajak tangguhan adalah salah satu pendekatan yang fungsinya mendeteksi praktek manajemen laba. Phillips menjelaskan bahwa, semakin tinggi laba fiskal dan laba akuntansi, mengindikasikan nilai diskresi manajemen 
(Phillips, et al., 2003). Artinya, semakin besar diskresi manajemen akan tercermin pada beban pajak tangguhan serta dapat diterapkan dalam mendeteksi praktek manajemen laba. Dan semakin besar praktek manajemen laba, semakin besar juga kewajiban pajak tangguhan yang diakui beban pajak tangguhan (Phillips, et al., 2003). Kerangka pemikiran penelitian yakni, memperlihatkan variabel independen dalam mempengaruhi variabel dependen. Perencanaan pajak dan beban pajak tangguhan merupakan variabel independennya, serta manajemen laba merupakan variabel dependennya. Berikut kerangka pemikiran penelitian terlihat dalam gambar 1:

\section{Gambar 1}

Kerangka Pemikiran

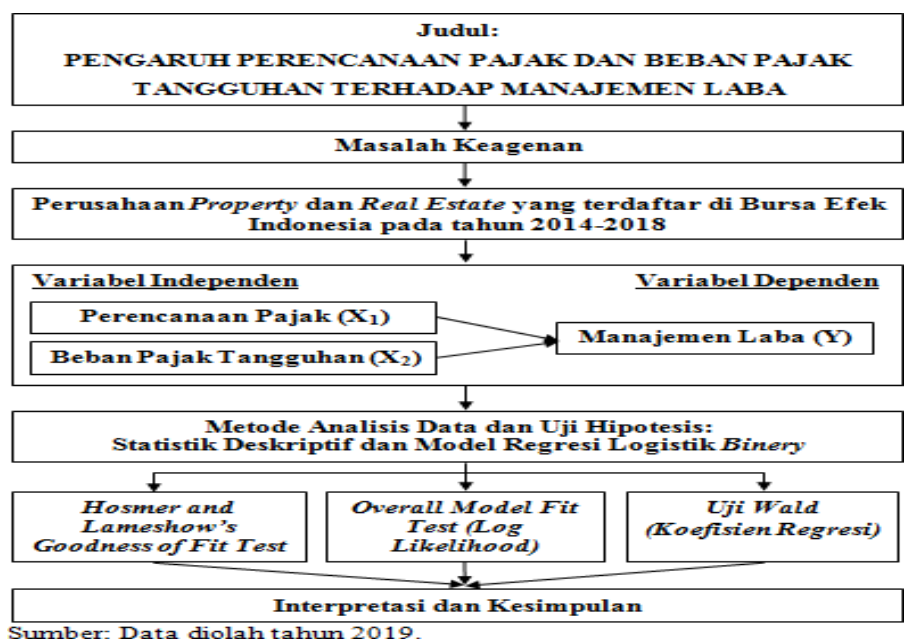

\subsection{HIPOTESIS}

$\mathrm{H}_{1}$ : Perencanaan pajak mempengaruhi praktek manajemen laba.

$\mathrm{H}_{2}$ : Beban pajak tangguhan mempengaruhi praktek manajemen laba.

\section{METODE PENELITIAN}

Jenis penelitian ini adalah kausalitas, yang memiliki tujuan menguji serta menyajikan data empirik mengenai variabel bebas, yakni perencanaan pajak dan beban pajak tangguhan terhadap variabel terikat, yakni manajemen laba. Menurut Indriantoro adanya persoalan akibat dan sebab guna menjelaskan pengaruh variabel $\mathrm{x}$ dengan variabel y, dikenal dengan penelitian kausalitas (Indriantoro, et al., 2014 : 28). Objek penelitian adalah laporan keuangan tahunan yang telah di audit oleh auditor independen pada perusahaan property dan real estate yang terdaftar di Bursa Efek Indonesia periode tahun 2014 sampai dengan tahun 2018. Subjek penelitian adalah Perusahaan property dan real estate yang terdaftar di Bursa Efek Indonesia periode pengamatan 5 tahun mulai tahun 2014 sampai dengan tahun 2018. Data eksternal dan sekunder dari website resmi Bursa Efek Indonesia yakni, www.idx.co.id. Penyusunan data dari 
entitas, kecuali peneliti dari entitas tersebut disebut data eksternal (Indriantoro, et al., 2014 : 149). Teknik pengumpulan data menggunakan observasi, riset kepustakaan dan dokumentasi. Populasinya semua perusahaan property dan real estate yang mempublikasikan annually report di BEI, serta telah di audit oleh auditor independen mulai tahun 2014 sampai dengan tahun 2018. Pemilihan sampel menggunakan metode purposive sampling yakni, menentukan sampel dengan kriteria yang ditetapkan peneliti.

Pengukuran variabel independen perencanaan pajak $\left(\mathrm{X}_{1}\right)$ menerapkan rumus tingkat retensi pajak atau tax retention rate, rumus ini menganalisa kemampuan manajemen pajak dalam laporan keuangan emiten tahun berjalan, yakni (Wild, et al., 2005):

$\mathrm{TRR}$ it $=\frac{\text { Net Income it }}{\text { Pretax Income }(\mathrm{EBIT}) \text { it }}$

Keterangan:

TRR it $=$ Tax retention rate (tingkat retensi pajak) perusahaan i pada tahun $\mathrm{t}$.

Net Income it $=$ Laba bersih perusahaan i pada tahun $\mathrm{t}$.

Pretax Income $(\mathrm{EBIT})$ it $\quad=$ Laba sebelum pajak perusahaan i pada tahun $\mathrm{t}$.

Pengukuran variabel independen beban pajak tangguhan $\left(\mathrm{X}_{2}\right)$ menerapkan rumus, yakni (Phillips, et al., 2003):

Keterangan:

$$
\text { DTE it }=\frac{\text { Deferred } \text { Tax Expense it }}{\text { Total Asset } \text { it }-1}
$$

DTE it

= Deferred tax expense (beban pajak tangguhan) perusahaan i pada tahun $t$.

Total Asset it $1 \quad$ = Total aset perusahaan i pada tahun $\mathrm{t}-1$ 
Pengukuran variabel dependen manajemen laba dikategorikan variabel dummy, yakni variabel bertipe klasifikasi, kategorik, atau dikotomi. Kategori 1 perusahaan pada posisi range small profit firms $(0-0,06)$, bertujuan menghindari pelaporan turunnya laba atau probabilitas menerapkan praktek manajemen laba. Kategori 0 perusahaan pada posisi range small loss firms (-0,09-0), bertujuan menghindari pelaporan rugi atau probabilitas tidak menerapkan praktek manajemen laba (Phillips, et al., 2003):

Scaled Earning Changes it $=\frac{\text { Net Income it }- \text { Net Income } \mathrm{i}(\mathrm{t}-1)}{\text { Market Value of Equity } \mathrm{i}(\mathrm{t}-1)}$

Keterangan:

Net Income it

$=$ Laba bersih perusahaan i pada tahunt .

Net Income i ( $\mathrm{t}-1)$

$=$ Laba bersih perusahaan i pada tahunt -1 .

Market Value of Equity i (t-1)

= Market value of equity perusahaan i pada tahun $\mathrm{t}-1$.

Dalam penelitian ini, peneliti menggunakan tingkat kapitalisasi sebagai proksi market value of equity. Nilai kapitalisasi tersebut diukur dengan mengalikan jumlah saham beredar perusahaan i pada akhir tahun t-1 dengan harga saham perusahaan i pada akhir tahun $\mathrm{t}-1$.

\section{HASIL DAN PEMBAHASAN}

Tabel 4.1.2.1

Proses Seleksi Sampel Perusahaan Property dan Real Estate

\begin{tabular}{|l|l|c|}
\hline No. & \multicolumn{1}{|c|}{ Kriteria } & Jumlah \\
\hline 1. & $\begin{array}{l}\text { Perusahaan property dan real estate yang terdaftar di BEI (Bursa } \\
\text { Efek Indonesia) dari tahun 2014 sampai dengan tahun 2018, } \\
\text { dengan tahun dasar 2013. }\end{array}$ & $\mathbf{4 5}$ \\
\hline 2. & $\begin{array}{l}\text { Perusahaan property dan real estate yang belum melaporkan } \\
\text { laporan keuangan tahunan (anually report) yang telah diaudit oleh } \\
\text { auditor independen dari tahun 2014 sampai dengan tahun 2018, } \\
\text { dan tidak mempublikasikan }\end{array}$ & (13) \\
\hline
\end{tabular}

laporan keuangan tahunan untuk tahun yang berakhir per 31 Desember. 


\begin{tabular}{|l|l|c|}
\hline 3. & $\begin{array}{l}\text { Perusahaan property dan real estate yang di-delisting selama } \\
\text { periode pengamatan tahun 2014 sampai dengan 2018. }\end{array}$ & (3) \\
\hline 4. & $\begin{array}{l}\text { Perusahaan property dan real estate yang tidak melaporkan beban } \\
\text { pajak tangguhan pada tahun 2014 sampai dengan tahun 2018. }\end{array}$ & $\mathbf{( 3 )}$ \\
\hline 5. & $\begin{array}{l}\text { Perusahaan property dan real estate yang melakukan akuisisi, } \\
\text { merger, restrukturisasi, dan perubahan kelompok usaha. Adanya } \\
\text { teruisisi, merger, restrukturisasi, serta perubahan kelompok usaha } \\
\text { sehingga mempengaruhi posisi dan kinerja keuangan perusahaan, } \\
\text { serta secara langsung meminimalkan beban pajaknya. }\end{array}$ & $\mathbf{( 2 )}$ \\
\hline 6. & $\begin{array}{l}\text { Perusahaan property dan real estate yang menggunakan mata } \\
\text { uang asing dalam laporan keuangan. }\end{array}$ & $\mathbf{( 0 )}$ \\
\hline \multicolumn{2}{|l|}{ Total Sampel Perusahaan } & $\mathbf{2 4}$ \\
\hline \multicolumn{2}{|l|}{ Tahun Penelitian } & $\mathbf{1 2 0}$ \\
\hline \multicolumn{2}{|l|}{ Total Sampel }
\end{tabular}

Sumber: Data diolah tahun 2019.

Dari hasil seleksi sampel pada tabel di atas, obyek penelitian yakni 24 perusahaan, periode penelitian 5 tahun dari tahun 2014 sampai dengan tahun 2018, sehingga total sampel $120(24 \times 5=120)$. Alat yang disesuaikan untuk membantu pengumpulan data peneliti, demi menjawab masalah penelitian. Peneliti menggunakan Microsoft Office Excel dan IBM SPSS Statistic 21 dengan metode statistik deskriptif dan metode regresi logistik biner.

Uji statistik deskriptif menerangkan variabel bebas yakni, perencanaan pajak dan beban pajak tangguhan dan variabel terikat yakni, manajemen laba. Olah data pada laporan keuangan tahunan 2014 sampai dengan tahun 2018. Berlandas pada hasil uji statistik deskriptif, didapat 120 data observasi pada perusahaan property dan real estate. Berikut hasil olah data statistik deskriptif, yakni: 
Tabel 4.1.3.1.1

\section{Hasil Uji Statistik Deskriptif}

Descriptive Statistics

\begin{tabular}{|c|c|c|c|c|c|}
\hline & $\mathrm{N}$ & Minimum & $\begin{array}{l}\text { Maximu } \\
\text { Mand }\end{array}$ & Mean & $\begin{array}{l}\text { Std. } \\
\text { Deviation }\end{array}$ \\
\hline Perencanaan Pajak & $\begin{array}{l}12 \\
0\end{array}$ & $-42,9836$ & 3,9044 &, 626010 & 4,0607697 \\
\hline Beban Pajak & 12 & $-9,1525$ & 8,8874 &, 287193 & 2,8434594 \\
\hline Tangguhan & 0 & & & & \\
\hline Manajemen Laba & 12 & 0 & 1 & ,48 & ,502 \\
\hline & 0 & & & & \\
\hline Valid N (listwise) & $\begin{array}{l}12 \\
0\end{array}$ & & & & \\
\hline
\end{tabular}

Sumber: Data diolah SPSS 21, tahun 2019.

Tabel tersebut memperlihatkan hasil dari masing-masing variabel, hasil statistik deskriptif perencanaan pajak, memperlihatkan nilai terendah -42,9836, nilai tertinggi 3,9044 , nilai rata-rata 0,626010 dan nilai standart deviasi 4,0607697 . Nilai rata-rata perencanaan pajak pada tahun 2014 sampai dengan tahun 2018 sebesar 0,626010, memperlihatkan bahwa rata-rata net profit perusahaan property dan real estate yang terdaftar di BEI pada tahun 2014 sampai dengan tahun 2018 lebih besar 62,601\% daripada earnings before interest tax tahun 2014 sampai dengan tahun 2018. Hasil statistik deskriptif beban pajak tangguhan, memperlihatkan nilai terendah $-9,1525$, nilai tertinggi 8,8874 , nilai rata-rata 0,287193 dan nilai standart deviasi 2,8434594 . Phillips menerangkan apabila nilai rata-rata beban pajak tangguhan positif, memberikan peringatan bahwa terjadi rugi atau kewajiban pajak tangguhan, sehingga rata-rata banyak pelaporan laba akuntansi lebih banyak dibanding pelaporan laba fiskal (Phillips, et al., 2003). Hasil analisis menggunakan statistik deskriptif terhadap manajemen laba, memperlihatkan nilai terendah 0 , nilai tertinggi 1 , nilai rata-rata 0,48 dan nilai standart deviasi 0,502. Phillips menyatakan bahwa, nilai rata-rata variabel manajemen laba positif, memperlihatkan bahwa rata-rata banyak perusahaan yang menerapkan praktek manajemen laba dengan maksud menghindari pelaporan turunnya laba (Phillips, et al., 2003).

Penelitian ini menggunakan metode regresi logistik binery. Model regresi ini bermaksud untuk meramal besarnya variabel terikat dengan menerapkan skala interval yang telah diketahui. Menurut Sarwono dan Budiono, data yang berskala kategorik atau nominal, terdiri dari dua probabilitas dikenal dengan variabel biner (Wisyam, 2017). Dalam observasi pada perusahaan property dan real estate, variabel terikatnya (Y) 
mempunyai tipe kategori, yaitu small loss firms $=0$ dan small profit firms $=1$. Seperti yang terlihat pada tabel 4.1.3.2.1 berikut:

Tabel 4.1.3.2.1

Identifikasi Data

Dependent Variable Encoding

\begin{tabular}{|l|c|}
\hline Original Value & Internal \\
\hline Small Loss Firms & \\
Small Profit Firms & \\
\hline
\end{tabular}

Sumber: Data diolah SPSS 21, tahun 2019

Pada observasi ini, jumlah data 120 atau $\mathrm{N}=120$. Demi mengkroscek lengkapnya data serta tidak ada missing case, berikut Tabel 4.1.3.2.2:

Tabel 4.1.3.2.2

Data yang Diproses

Case Processing Summary

\begin{tabular}{|ll|r|r|}
\hline Unweighted Cases $^{\mathrm{a}}$ & $\mathrm{N}$ & Percent \\
\hline & Included in Analysis & 120 & 100,0 \\
Selected Cases & Missing Cases & 0 &, 0 \\
& Total & 120 & 100,0 \\
Unselected Cases & & 0 &, 0 \\
Total & & 120 & 100,0 \\
\hline
\end{tabular}

a. If weight is in effect, see classification table for the total number of cases

Sumber: Data diolah SPSS 21, tahun 2019.

Pada proses observasi pengujian menerapkan uji regresi logistik binery, yakni (Ghozali, $2013:$ 340): 


\section{Menilai Kelayakan Model Regresi}

Penilaian layak tidaknya model regresi menggunakan Hosmer and Lemeshow's Goodness of Fit Test. Pemodelan ini berguna dalam pengujian hipotesia nol bahwa data empirik sama dengan model (model sama dengan data, maka model dikatakan fit). Apabila nilai statistik Hosmer and Lemeshow's Goodness of Fit Test < 0,05 maka hipotesa nol tidak diterima, yang artinya ada beda signifikan antara model dengan nilai observasi sehingga Goodness Fit Model tidak baik karena model tidak bisa meramal nilai observasi. Apabila nilai statistik Hosmer and Lemeshow's Goodness of Fit Test > 0,05 maka hipotesa nol diterima, serta model dapat meramal nilai observasi (Ghozali, 2013 : 341).

Tabel 4.1.3.2.3

\section{Kelayakan Model Regresi}

Hosmer and Lemeshow Test

\begin{tabular}{|c|c|c|c|}
\hline Step & Chi-square & $\underset{\mathrm{f}}{\mathrm{D}}$ & $\mathrm{Sig}$ \\
\hline 1 & 13,447 & 8 & ,097 \\
\hline
\end{tabular}

Sumber: Data olahan SPSS 21, tahun 2019.

Dalam pengujian kelayakan model regresi, nilai Chi-square tabel untuk DF 8 dengan taraf sig 0,05 senilai 15,507. Dari output yang diperoleh, nilai Chi-square Hosmer and Lemeshow's hitung sebesar 13,447 < Chi-square tabel 15,507 dengan kemungkinan $0,97>0,05(\mathrm{p}>0,05)$, sehingga menerima $\mathrm{H}_{0}$, sehingga model diterima dan hipotesa dapat meramal nilai observasi.

\section{Hasil Uji Keseluruhan Model (Overall Model Fit)}

Ghozali berpendapat bahwa, apabila nilai $-2 \log L$ awal dengan $-2 \log L$ berikutnya terjadi penurunan atau pengurangan, membuktikan bahwa model hipotesa fit dengan data (Ghozali, 2013 : 341). Log Likelihood sama dengan Sum of Square Error dalam model regresi, penurunan nilai tersebut mencerminkan model regresi semakin baik.

Pada output tabel di bawah ini menunjukkan penurunan nilai -2Log Likelihood awal (block number $=0$ ) sebesar 166,222 serta pada -2 Log Likelihood berikutnya (block number $=1$ ) sebesar 164,943 . Output tersebut menunjukkan model regresi terjadi penurunan nilai Likelihood (-2LL), memperlihatkan model regresi yang bagus atau model hipotesa fit dengan data. 
Tabel 4.1.3.2.4

Tabel Uji Overall Model Fit

(block number $=0$ )

Iteration History ${ }^{a, b, c}$

\begin{tabular}{|c|c|c|}
\hline \multirow[t]{2}{*}{ Iteration } & \multirow{2}{*}{$\begin{array}{l}-2 \text { Log } \\
\text { likelihood }\end{array}$} & $\begin{array}{l}\text { Coefficien } \\
\text { ts }\end{array}$ \\
\hline & & Constant \\
\hline \multirow{2}{*}{ Step U } & 166,222 &,- 067 \\
\hline & 166,222 & $-0,6 /$ \\
\hline
\end{tabular}

a. Constant is included in the model.

b. Initial -2 Log Likelihood: 166,222

c. Estimation terminated at iteration number 2 because parameter estimates changed by less than ,001.

Sumber: Data diolah SPSS 21, tahun 2019.

Tabel 4.1.3.2.5

Tabel Uji Overall Model Fit

$($ block number $=1)$

Iteration History ${ }^{\mathrm{a}, \mathrm{b}, \mathrm{c}, \mathrm{d}}$

\begin{tabular}{|c|c|c|c|c|}
\hline \multirow{2}{*}{$\begin{array}{l}\text { Iteratio } \\
\mathrm{n}\end{array}$} & \multirow{2}{*}{$\begin{array}{l}-2 \log \\
\text { likeliho } \\
\text { od }\end{array}$} & \multicolumn{3}{|c|}{$\underset{\text { nts }}{\text { Coefficie }}$} \\
\hline & & Constant & $\begin{array}{r}\text { Perencanaan_Paj } \\
\text { ak }\end{array}$ & $\begin{array}{r}\text { Beban_Pajak_Tanggu } \\
\text { han }\end{array}$ \\
\hline 1 & 164,943 &,- 039 &,- 048 & ,007 \\
\hline 2 & 164,771 &,- 013 &,- 074 & ,007 \\
\hline 3 & 164,727 & ,008 &,- 094 & ,007 \\
\hline 4 & 164,720 & ,020 &,- 106 & ,008 \\
\hline
\end{tabular}




\begin{tabular}{|r|r|r|r|r|}
5 & 164,720 &, 022 &,- 109 &, 008 \\
6 & 164,720 &, 022 &,- 109 &, 008 \\
\hline
\end{tabular}

a. Method: Enter

b. Constant is included in the model.

c. Initial -2 Log Likelihood: 166,222

d. Estimation terminated at iteration number 6 because parameter estimates changed by less than ,001.

Sumber: Data diolah SPSS 21, tahun 2019.

\section{Hasil Uji Koefisien Determinasi $\left(\mathbf{R}^{2}\right)$}

Jumlah nilai koefisien determinasi dalam model regresi logistik biner pada perusahaan property dan real estate ditunjukkan pada nilai Nagelkerke $R$ Square 0,017 atau $1,7 \%$ dengan arti variabel perencanaan pajak dan variabel beban pajak tangguhan dalam mempengaruhi variabel manajemen laba senilai $1,7 \%$ serta sisanya $98,3 \%$ yang mempengaruhi variabel lain diluar model. Nilai 0,017 menjelaskan adanya korelasi yang lemah dan tidak signifikan antara variabel bebas terhadap variabel terikat.

Tabel 4.1.3.2.6

Koefisien Cox \& Snell R Square dan Negelkerke R Square

Model Summary

\begin{tabular}{|c|c|c|c|}
\hline Step & $\begin{array}{l}-2 \text { Log } \\
\text { likelihood }\end{array}$ & Cox \& $\underset{\text { Squell R }}{\text { Rquare }}$ & $\begin{array}{l}\text { Nagelkerke R } \\
\text { Square }\end{array}$ \\
\hline 1 & $0^{\mathrm{a}}$ & ,012 & 017, \\
\hline
\end{tabular}

a. Estimation terminated at iteration number 6 because parameter estimates changed by less than ,001.

Sumber: Data diolah SPSS 21, tahun 2019

\section{Hasil Uji Tabel Klasifikasi}

Berlandaskan tabel di bawah, ditunjukkan kekuatan ramalan probabilitas perusahaan menerapkan praktek manajemen laba sebesar 3,4\%. Hal tersebut menjelaskan pada model regresi terdapat 2 sampel perusahaan $(3,4 \%)$ yang diramal menerapkan praktek manajemen laba dari 58 sampel perusahaan yang menerapkan praktek manajemen laba.

Kuatnya model regresi dalam meramal probabilitas perusahaan tidak menerapkan praktek manajemen laba sebesar 95,2\%. Hal tersebut menjelaskan pada model regresi 
terdapat 59 sampel perusahaan $(95,2 \%)$ yang diramal tidak menerapkan praktek manajemen laba dari 62 sampel perusahaan yang tidak menerapkan praktek manajemen laba. Dari output persamaan regresi logistik, penelitian ini memeperlihatkan kekuatan penegelompokkan ketepatan peramalan seluruhnya senilai 50,8\%.

Tabel 4.1.3.2.7

Hasil Uji Klasifikasi

Classification Table ${ }^{a}$

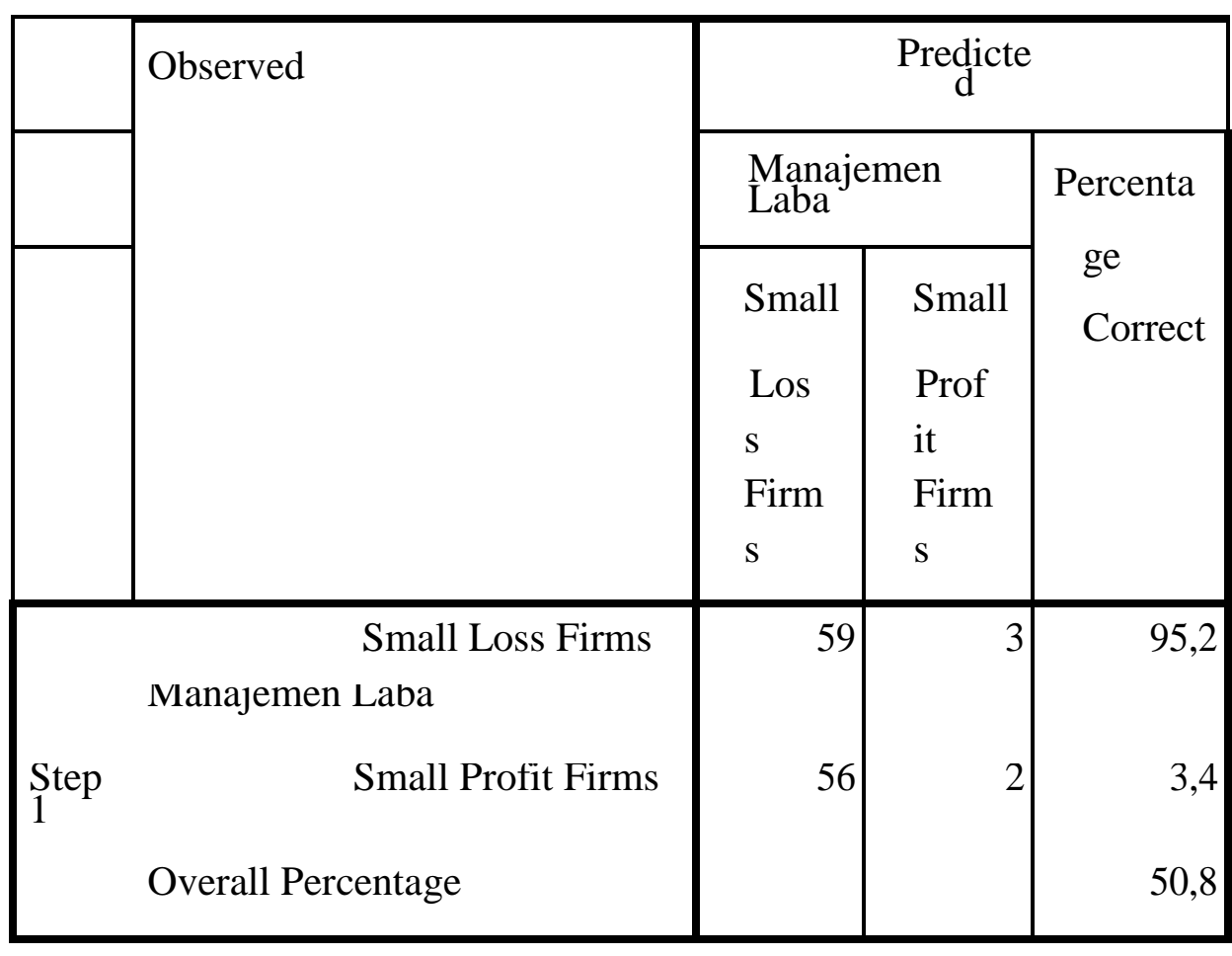

cut value is ,500

a. The

Sumber: Data diolah SPSS 21, tahun 2019.

\section{Hasil Uji Koefisien Regresi Logistik}

Uji hipotesa pada regresi ini dengan membandingkan nilai kemungkinan (sig). Jika terdapat nilai signifikan $<0,05$, maka menolak $\mathrm{H}_{0}$ serta menerima $\mathrm{H}_{1}$, sehingga variabel independen mempengaruhi variabel dependen secara signifikan. Output koefisien regresi ditentukan melalui nilai kemungkinan (sig) dalam tabel berikut: 
Tabel 4.1.3.2.8

Hasil Uji Koefisien Regresi Logistik

Variables in the Equation

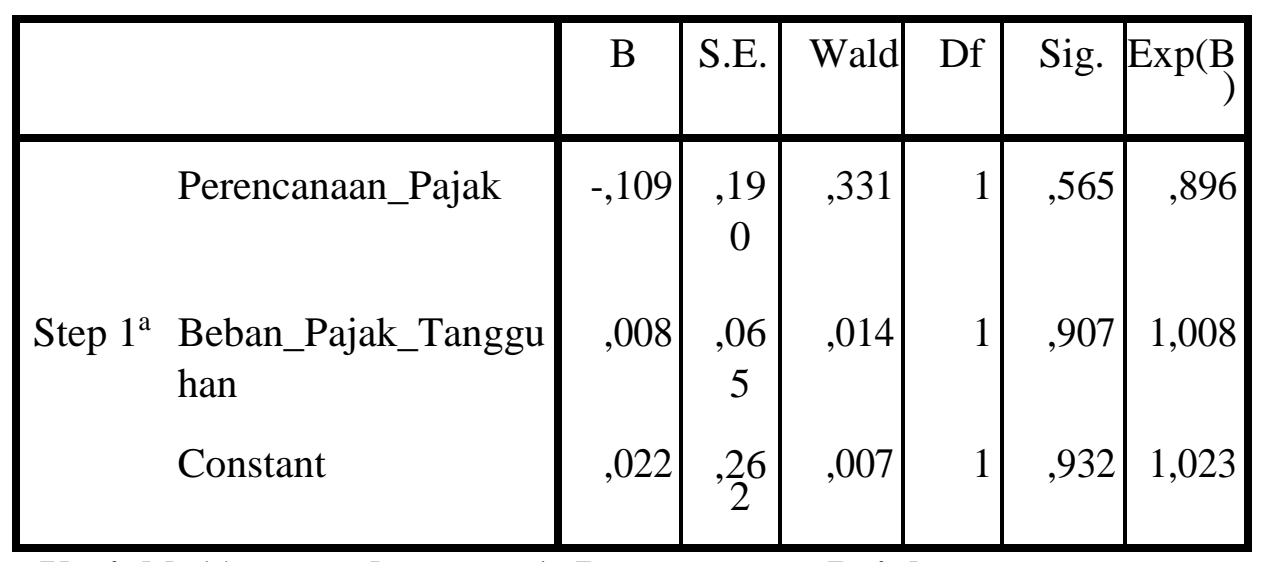

\section{a. Variable(s) entered on step 1: Perencanaan_Pajak, Beban_Pajak_Tangguhan.}

Sumber: Data diolah SPSS 21, tahun 2019.

Output uji koefisien regresi logistik diperoleh model sebagai berikut:

$$
\begin{aligned}
& \operatorname{Ln} \frac{\mathrm{EM}}{1-\mathrm{EM}}=0,022-0,109 \text { TRRit }+0,008 \text { DTEit }+0,05 \\
& \operatorname{Ln} \frac{\mathrm{EM}}{1-\mathrm{EM}}=\alpha+\beta_{1} \text { TRRit }+\beta_{2} \text { DTEit }+\varepsilon
\end{aligned}
$$

Pada tabel di atas, ditunjukkan perencanaan mempunyai nilai koefisien -0,109 dan sig sebesar 0,565 > taraf sig alpha 0,05 dengan arti, perencanaan pajak memiliki pengaruh negatif yang lemah kepada manajemen laba. Semakin besar perencanaan pajak maka, semakin kecil probabilitas perusahaan menerapkan praktek manajemen laba pada bingkai perpajakan, serta dapat disimpulkan perencanaan pajak berpengaruh tidak signifikan kepada praktek manajemen laba.

Berbeda dengan beban pajak tangguhan mempunyai nilai koefisien 0,008 dan sig sebesar 0,907 > taraf sig alpha 0,05 dengan artian, beban pajak tangguhan mempunyai pengaruh positif kepada praktek manajemen laba yakni, memperlihatkan fleksibilitas beban pajak tangguhan dengan profitabilitas perusahaan menerapkan praktek manajemen laba, dengan arti jika beban pajak tangguhan naik $1 \%$ sehingga, kemungkinan perusahaan menerapkan praktek manajemen laba akan naik $1 \%$. Sebaliknya jika beban pajak tangguhan turun $1 \%$ sehingga, kemungkinan perusahaan menerapkan praktek manajemen laba akan turun $1 \%$. Kesimpulannya beban pajak tangguhan mempengaruhi praktek manajemen laba tidak signifikan. 


\subsection{Pembahasan Hasil Penelitian}

Pada analisa output statistik deskriptif perencanaan pajak tahun 2014 sampai dengan tahun 2018, nilai rata-rata 0,626010 menunjukkan bahwa, rata-rata net profit pada perusahaan property dan real estate yang terdaftar di BEI pada tahun 2014 sampai dengan tahun 2018, lebih besar 62,601\% daripada earnings before interest tax tahun 2014 sampai dengan tahun 2018. Kemungkinan hal itu terjadi, dikarenakan pengakuan beban terpulihkan pada jangka pendek tidak menerima dampak transitoris (pendapatan yang sudah diterima kasnya, akan tetapi belum menjadi hak perusahaan dan biaya yang sudah dibayar dengan kas, akan tetapi belum menjadi kewajiban perusahaan) pada berbedaan tersebut. Dampak dari perbedaan metode pengakuan, maka terjadi pengurangan biaya besar-besaran pada kalkulasi profit menurut akuntansi dan laba fiskal yang harusnya ditambahkan, malah dilakukan pengurangan, sehingga berdampak pada tingginya profit.

Sedangkan pada analisa output statistik deskriptif beban pajak tangguhan memperlihatkan nilai rata-rata 0,287193. Berlandaskan teori yang diungkapkan oleh Phillips bahwa, apabila nilai rata-rata beban pajak tangguhan positif memberikan peringatan bahwa terjadi rugi atau kewajiban pajak tangguhan, sehingga rata-rata banyak pelaporan laba akuntansi lebih besar dibanding laba fiskal. Serta pada analisa output statistik deskriptif manajemen laba, menunjukkan nilai rata-rata 0,48. Menurut Phillips, apabila nilai rata-rata manajemen laba positif, memperlihatkan bahwa banyak perusahaan yang menerapkan praktek manajemen laba dengan maksud menghindari turunnya laba (Phillips, et al., 2003). Penelitian ini sejalan dengan penelitian Aditama, et al. (2014) serta tidak sejalan dengan penelitian Widiastuti, et al. (2011), Yulianti (2005), dan Herdawati (2015).

Prediksi power model regresi dalam memprediksi probabilitas perusahaan menerapkan praktek manajemen laba adalah 3,4\% serta prediksi power model regresi dalam memprediksi probabilitas perusahaan tidak melakukan praktek manajemen laba adalah 95,2\%. Dari output persamaan regresi logistik pada penelitian ini memperlihatkan kemampuan pengelompokkan ketepatan meramal keseluruhan sebesar 50,8\% dengan kesimpulan, perusahaan diramal tidak melakukan praktek manajemen laba lebih kuat dibanding perusahaan yang melakukan praktek manajemen laba.

Serta output uji koefisien determinasi yang mengenakan Nagelkerke $R$ Square menunjukkan porsi perencanaan pajak dan beban pajak tangguhan pada perusahaan property dan real estate yang terdaftar di BEI pada tahun 2014 sampai dengan tahun 2018 berlinier positif. Nilai Nagelkerke $R$ Square dalam penelitian ini 0,017 atau 1,7\% yang artinya setiap perubahan variabel terikat (manajemen laba) bisa diuraikan oleh variabel bebas (perencanaan pajak) dan (beban pajak tangguhan) senilai 1,7\% serta sisanya $98,3 \%$ bisa diuraikan oleh variabel di luar model. Semakin meningkatnya nilai Nagelkerke $R$ Square pada suatu regresi, maka hubungan variabel bebas dan variabel terikat pada penelitian akan semakin kuat (Herdawati, 2015).

Berdasarkan output uji regresi logistik biner dalam penelitian ini, memperlihatkan variabel perencanaan pajak mempunyai pengaruh negatif pada variabel manajemen laba, semakin besar perencanaan pajak maka, semakin kecil probabilitas perusahaan melakukan 
praktek manajemen laba dalam bingkai perpajakan pada perusahaan property dan real estate yang terdaftar di BEI pada tahun 2014 sampai dengan tahun 2018. Perencanaan pajak memiliki nilai sig sebesar 0,565 > taraf sig alpha 0,05 artinya, perencanaan pajak berpengaruh tidak signifikan kepada praktek manajemen laba. Jumlah nilai rata-rata variabel manajemen laba pada statistik deskriptif memperlihatkan nilai positif, berlandaskan teori yang dijelaskan oleh Phillips, et al. (2003), menjelaskan upaya perusahaan dalam melakukan praktek manajemen laba dengan maksud menghindari turunnya laba. Atau dengan sinonim menerima $\mathrm{H}_{1}$, perencanaan pajak mempunyai pengaruh negatif serta tidak signifikan pada praktek manajemen laba dengan menghindari turunnya laba, maka di diagnosa perusahaan property dan real estate yang terdaftar di BEI tahun 2014 sampai dengan tahun 2018 lebih mengutamakan profit akuntansi dibanding dengan laba fiskal yaitu, bonus plan hypotesis pada teori akuntansi positif seperti pemaparan Watt dan Zimmerman bahwa, pihak manajemen lebih memilih metode akuntansi dalam pemaksimalan utilitas, yakni bonus besar. Manajer perusahaan yang memberikan bonus tinggi berdasar laba, rata-rata menerapkan metode akuntansi dalam peningkatan laba yang dilaporkan (Scott, 2000). Serta menurut Scott, manajer akan berusaha meningkatkan jumlah pelaporan profit, demi memberikan pengaruh keputusan investasi yang dilakukan investor (Scott, 2006 : 70). Output pada penelitian ini sejalan dengan penelitian Aditama, et al. (2014), Sumomba (2012) serta tidak sejalan dengan penelitian Santana (2016), Negara, et al. (2017), dan Herdawati (2015).

Berbeda dengan output uji regresi logistik dalam beban pajak tangguhan memiliki pengaruh positif pada manajemen laba, yang berarti semakin besar beban pajak tangguhan, maka probabilitas perusahaan dalam menerapkan praktek manajemen laba semakin besar juga. Beban pajak tangguhan mempunyai nilai sig sebesar 0,907 > taraf sig alpha 0,05 dengan artian, beban pajak tangguhan mempunyai pengaruh namun tidak signifikan pada praktek manajemen laba. Nilai rata-rata variabel manajemen laba dalam statistik deskriptif memperlihatkan nilai positif, berlandaskan teori yang diungkapkan Phillips, et al. (2003), memperlihatkan upaya perusahaan dalam melakukan praktek manajemen laba dengan maksud menghindari turunnya laba. Dengan sinonim, menerima $\mathrm{H}_{2}$. Pengukuran beban pajak tangguhan dengan memperbandingkan beban pajak tangguhan perusahaan pada tahun $\mathrm{t}$, dengan total aktiva pada perusahaan tahun $\mathrm{t}-1$, tidak mempunyai pengaruh signifikan pada praktek manajemen laba. Kekuatan beban pajak tangguhan hanya memperlihatkan efek pajak yang timbul karena beda temporer antara kalkulasi akuntansi dan kalkulasi fiskal. Jika perusahaan ter diagnosa menerapkan praktek manajemen laba dengan memperlihatkan beda permanen, akibatnya beban pajak tangguhan tidak mampu mendeteksi aktivitas praktek manajemen laba. Output penelitian ini sejalan dengan penelitian Phillips, et al. (2003), Sumomba, et al. (2012), Herdawati (2015), Negara, et al. (2017), Wisyam (2017) dan tidak sejalan dengan Yulianti (2005). 


\section{KESIMPULAN DAN SARAN}

\section{Kesimpulan}

Dari hasil penelitian dan pengujian hipotesis, maka dapat diambil kesimpulan yakni:

a. Pada penelitian ini, perencanaan pajak mempunyai pengaruh yang negatif serta tidak signifikan dalam mempengaruhi praktek manajemen laba. Maksud dari pengaruh yang negatif yaitu semakin besar perusahaan melakukan perencanaan pajak, maka semakin kecil peluang serta probabilitas perusahaan melakukan manajemen laba dalam bingkai perpajakan (begitu pula sebaliknya). Meski pengaruh perencanaan pajak ini lemah, tapi masih banyak faktor lain yang memungkinkan perusahaan dalam melakukan praktek manajemen laba. Motivasi kemungkinan yang melatarbelakangi tindakan perusahaan lebih mementingkan laba akuntansi dibandingkan dengan laba fiskal yaitu, bonus plan hypothesis dalam teori akuntansi positif (Scott, 2000) serta perusahaan berjuang dalam meningkatkan jumlah profit yang dilaporkan, untuk mempengaruhi keputusan yang diambil investor (Scott, 2006 : 70). Otomatis hasil dari penelitian serta uji hipotesis ini memaparkan bahwa perencanaan pajak dapat mempengaruhi praktek manajemen laba dengan menghindari turunnya laba pada perusahaan property dan real estate yang terdaftar di BEI tahun 2014-2018, sehingga menerima $\mathrm{H}_{1}$ pada penelitian ini.

b. Dalam penelitian ini, beban pajak tangguhan memiliki pengaruh yang positif serta tidak signifikan dalam mempengaruhi praktek manajemen laba. Maksud dari pengaruh yang positif yaitu setiap beban pajak tangguhan naik, maka kemungkinan atau probabilitas perusahaan dalam melakukan praktek manajemen laba mengalami peningkatan (begitu pula sebaliknya). Otomatis hasil penelitian dan uji hipotesis ini memaparkan bahwa beban pajak tangguhan dapat digunakan dalam mendeteksi adanya praktek manajemen laba dengan maksud perusahaan menghindari terjadi turunannya laba, pada perusahaan property dan real estate yang terdaftar di BEI tahun 2014-2018, sehingga menerima $\mathrm{H}_{2}$ pada penelitian ini.

\section{Saran}

Berlandaskan dari pembahasan serta simpulan, penulis memberi masukan kepada peneliti yang akan datang. Apabila bermaksud untuk meneliti dengan pokok permasalahan hampir sama dengan penelitian ini, yakni:

a. Peneliti dapat menambah variabel independen lain seperti variabel aktiva, penjualan, laba, tingkat hutang, pajak kini dan lain-lain, yang di diagnosa kuat dapat mendeteksi adanya praktek manajemen laba.

b. Peneliti dapat menambahkan sampel penelitian, seperti semua bidang usaha yang terdaftar di BEI tidak terkecuali, seperti pada penelitian ini yang hanya meneliti bidang usaha property dan real estate.

c. Peneliti dapat memproksikan manajemen laba dengan diskresi maupun akrual dalam beberapa model, sehingga diharapkan dapat memperakurat hasil pendeteksian praktek manajemen laba. 


\subsection{Implikasi dan Keterbatasan}

Dalam penelitian ini masih banyak kekurangan serta keterbatasan yang bisa berpengaruh pada hasil penelitian, berikut keterbatasan yang dirasa peneliti dapat menghambat kesempurnaan hasil penelitian, yakni:

a. Sampel penelitian pada penelitian ini hanya berlingkup pada satu bidang usaha yakni property dan real estate yang terdaftar di BEI tahun 2014-2018. Otomatis hasil penelitian tidak bisa dipakai untuk dasar umum penelitian. Peneliti yang akan datang, diharap bisa menambah bidang usaha serta periode pengamatan yang panjang, seperti periode 10 tahun agar mendapat hasil yang lebih akurat.

b. Variabel independen pada penelitian ini hanya dua, sehingga rana penelitian ini hanya mencari seberapa kuat hubungan dan pengaruhnya variabel independen terhadap probabilitas variabel dependennya saja. 


\section{DAFTAR PUSTAKA}

Aditama, Ferry dan Purwaningsih, Anna. 2014. Pengaruh Perencanaan Pajak Terhadap Manajemen Laba Pada Perusahaan Nonmanufaktur Yang Terdaftar Di Bursa Efek Indonesia. MODUS Vol.26 : p.33-50.

Agoes, Sukrisno dan Trisnawati, Erlita. 2013. Akuntansi Pajak. Edisi 3. Jakarta : Penerbit Salemba Empat.

Belkaoui, Ahmed Riahi. 2006. Teori Akuntansi. Buku Satu Edisi 5. Terjemahan Ali Akbar Yulianto dan Risnawati Dermauli. Jakarta : Penerbit Salemba Empat.

Ghozali, Imam. 2013. Aplikasi Analisis Multivariate Dengan Program IBM SPSS

21. Semarang : Badan Penerbit Universitas Diponegoro.

Harnanto. 2011. Akuntansi Perpajakan. Yogyakarta : Penerbit BPFE-Yogyakarta.

Herdawati. 2015. Analisis Pengaruh Perencanaan Pajak Dan Beban Pajak Tangguhan Terhadap Manajemen Laba Studi Kasus Pada Perusahaan Manufaktur Yang Tercatat Di Bursa Efek Indonesia. Skripsi. Jurusan Akuntansi Fakultas Ekonomi Dan Bisnis Universitas Hasanuddin. Makasar.

Indriantoro, N. dan Supomo, B. 2014. Metodologi Penelitian Bisnis Untuk Akuntansi dan Manajemen. Yogyakarta : Penerbit BPFE-Yogyakarta.

Lumbantoruan, Sophar. 1996. Akuntansi Pajak. Edisi Revisi. Jakarta : Penerbit PT Gramedia Widiasarana Indonesia.

Negara, A.A Gede Raka Plasa dan Suputra, I.D.G Dharma. 2017. Pengaruh Perencanaan Pajak Dan Beban Pajak Tangguhan Terhadap Manajemen Laba. E-Jurnal Akuntansi Universitas Udayana Vol.20.30. September : p.2045- 2072.

Phillips, John., M. Pincus and S. Rego. 2003. Earnings Management New Evidence Based on Deferred Tax Expense. The Accounting Review Vol. 78, No. 2. April : p.491-521.

Purba, Marisi. 2009. Akuntansi Pajak Penghasilan. Yogyakarta : Penerbit Graha Ilmu.

Santana, Dewa Ketut Wira dan Wirakusuma, Made Gede. 2016. Pengaruh Perencanaan Pajak, Kepemilikan Manajerial dan Ukuran Perusahaan Terhadap Praktek Manajemen Laba. E-Jurnal Akuntansi Universitas Udayana Vol.14.3 : p.55-83.

Scott, William R. 2000. Financial Accounting Theory. 2nd Edition. Scarrborough Ontario : Prentice Hall International, Inc.

Scott, William R. 2006. Financial Accounting Theory. Toronto : Pearson Education Canada, Inc.

Suandy, Erly. 2014. Perencanaan Pajak. Edisi 5. Jakarta : Penerbit Salemba Empat.

Sulistyanto, Sri. 2008. Manajemen Laba Teori dan Model Empiris. Jakarta : Penerbit Grasindo. 
Sumomba, Christina Ranty dan Hutomo, YB. Sigit. 2012. Pengaruh Beban Pajak Tangguhan Dan Perencanaan Pajak Terhadap Manajemen Laba. KINERJA Vol.16 : p.103-115.

Watt, R.L., and Zimmerman, J.L. 1990. Positive Accounting Theory: A Ten Year Perspective. The Accounting Review. Vol. 65. No. 1.

Widiastuti, Ni Putu Eka dan Chusniah, Elsa. 2011. Analisis Aktiva Pajak Tangguhan dan Discretionary Accrual Sebagai Prediktor Manajemen Laba Pada Perusahaan Yang Terdaftar Di BEI. Econo Sains Vol IX, No. 1. Maret : p.28-40.

Wild, John J., K.R. Subramanyam and Robert F. Halsey. 2005. Financial Statement Analysis (Analisis Laporan Keuangan). Edisi 8 Buku Satu. Jakarta : Penerbit Salemba Empat.

Wisyam, Muhammad Akbar. 2017. Pengaruh Deffered Tax Expense dan Akrual Terhadap Earning Management. Skripsi. Jurusan Akuntansi Fakultas Ekonomi dan Bisnis Universitas Islam Negeri Syarif Hidayatullah. Jakarta.

Yulianti. 2005. Kemampuan Beban Pajak Tangguhan Dalam Memprediksi Manajemen Laba. Jurnal Akuntansi dan Keuangan Indonesia Vol. 2, No. 1. Juli : p.107-129.

Zain, Mohammad. 2003. Manajemen Perpajakan. Jakarta : Penerbit Salemba Empat. 